being Sir Edward Frankland in chemistry, Sir Richard Owen in biology, Prof. Seward in botany, and Prof. Marr in geology. A letter of support was read from Prof. P. F. Frankland. Prof. Armstrong is to be president of the new society, which, it has been decided, shall be called the Lancaster Frankland Chemical Society.

\section{Biology's Message for Civilisation}

IN an address to Sections D and F of the South African Association for the Advancement of Science in July 1932, Prof. H. B. Fantham, recently elected to the chair of zoology in McGill University, Montreal, essayed to interpret biology's message for the plight of modern civilisation (South African J. Sci., vol. 29, p. 533). Prof. Fantham regards the expenditure on education as excessive, and the subjects taught too many ; his own ideal list includes general elementary science (including biology), the languages of the country, reading; writing, arithmetic, economic and human geography, history, some cultural subject like singing, needlework and cookery for girls, drawing and woodwork for boys, moral principles, and perhaps simple drill, anything beyond these to be paid for by the parents concerned. Elementary education alone should be free, for so-called free education is 'free' only to the parents directly concerned and not to the community. The mechanisation of the modern world is a disharmony, which is narrowing and starving human life. Doles are "perhaps the greatest biological mistake in the social organisation of the present age" ; relief should be made conditional on the giving of service. Generally, Prof. Fantham holds that there is too much administration, too much organisation, too many conferences and too much mechanisation, so that man's environment has become too artificial, and the result of the disharmony is expressed in instability and unrest. Some suggestions made by the author are that government must be by paid business managers trained in science and administration; that production must be adjusted to demand and the scientific organisation of distribution; that wages should be judged by their purchasing power; that the movement back to the land should be encouraged; that wars should cease and war debts be cancelled; and that eugenic measures should be employed to cope with problems of over-population.

\section{The Language Difficulty and Scientific Progress}

DURING the course of a year we receive many journals, reports of congresses, and papers printed in languages which, it must be admitted, are unfamiliar to the majority of scientific workers and sometimes in alphabets which add to the difficulties of interpretation. Fortunately, the custom is growing of adding to each paper a summary of its contents in English, French or German, but no summary can ever replace, for a scientific worker, the detail of the method and observations of the paper sum. marised. The relegating to comparative obscurity, on account of the language difficulty, of many papers of value is all against the progress of scientific know. ledge, and it is for that reason that we venture to appeal again for an increased use, if not in whole at least in summary, of the languages which have come to be recognised as the general vehicle of scientific researches. The tendency of recent times was the subject of discussion at the fifteenth annual meeting of the American Society of Ichthyologists and Herpetologists in Washington, D.C., in May 1932, and the following resolution was passed unanimously : "Whereas, a large number of ichthyologists and herpetologists of countries using non-Latin alphabets are publishing their papers in the English language; therefore, be it resolved that the American ichthyologists and herpetologists, through their Society, desire to thank their fellow scientists of other lands for publishing in English."

\section{Use of the English Language}

AT the Friday evening discourse at the Royal Institution on February 3, Dr. Cyril Norwood discussed the use of the English language. Dr. Norwood directed attention to the particular dangers to present-day writers arising from the rapid wear and tear of words and phrases, and the decay of metaphors, and pointed out that these arise from, among other things, the excessive use of technical language which reduces words to a system of symbols. Illustrations from the works of leader writers and of men of science were given to show the kinds of error which are very frequent, and to illustrate methods of style which delay the reader's appre. hension and defeat the writer's object. The methods of Darwin, who was without natural gifts of style, but took infinite pains to render his writing clear and attractive, were examined and Dr. Norwood suggested that Darwin's example could well be followed. A similar study of Huxley was made, and Dr. Norwood quoted a passage from his writings which he considers is a model of written English.

\section{Economic Value of Agricultural Science}

There must be few engaged in research who have not been called upon to justify the policy of scientific examination of technical problems in face of the apathy or distrust of the practical man. This is particularly so in the case of agriculture, in which it is still possible to continue by the use of traditional methods. Fortunately, the list of scientific achievements which have given the cultivator vastly greater command over the forces of Nature is a long one; and the critic may be made to realise that practically the whole agricultural technique that was not possessed by his grandfather is the direct outcome of scientific research. In an address delivered to the Wellington Philosophical Society on October 26, Lord Bledisloe, Governor General of New Zealand, very ably sets out the economic value of agricultural science. Addressing his remarks to the primary producer, Lord Bledisloe points out that only by fostering scientific research and applying its results to practice can a place be maintained in world markets, continually more congested and more exacting 
in their requirements. Research, however, must be thorough, tested out in all its bearings, and put before farmers as a sound investment. Surveying the whole agricultural field, the leading achievements of agricultural research which have led to definite economic results are touched on, and even to those familiar with the subject the cumulative result is impressive. The problem of production has been solved. The famines predicted from time to time in the recent past are not likely to trouble us. The need for the future is to get into wider circulation the plenty which improved methods have secured.

\section{Gold and Silver Currencies}

IN a recent publication (" "Standard Gold' and Silver : the Way out of the Crisis." Pp. 88. Manchester : Taylor Garnett Evans and Co., Ltd., 1932), Dr. Ernest Zucker advocates the devaluation of the world's gold currencies by means of a onethird reduction in the gold content of the standard coins. He also advocates the introduction of silver as a subsidiary currency to facilitate trade with the silver-using East. The effect of the first proposal, he argues, would be to raise the prices of raw materials and similar commodities by about half, since their prices are world prices based on gold. The purchasing power of wages and salaries, on the other hand, would be reduced by about a third. In this way the disequilibrium between the prices of raw materials and manufactured products could be removed, while inter-allied debts and reparations would be reduced by a third. Dr. Zucker's scheme, however, presents serious difficulties. First there is the practical problem of securing common action among creditor nations, especially the United States and France. Secondly, devaluation would not in itself re-adjust the maldistribution of gold. Creditor countries would continue to attract the world's gold and if they persisted in high tariff policies, it would still be difficult for debtor countries to make payments, or for the volume of world trade to be increased.

\section{Daily Mail Ideal Home Exhibition}

THe Daily Mail Ideal Home Exhibition will be open at Olympia, London, W., on March 29-April 29. According to advance information recent developments in illumination will be utilised to ereate in the Grand Hall of Olympia, a 'Rainbow City'. The colours of a great rainbow, appearing from among 'clouds of depression', will be produced by a gigantic scheme of neon lighting, and the eye will travel back over a hall in rainbow hues to 'the sun of prosperity'. Scientific workers will be attracted by a series of "Rooms of the Scientists" on the first floor of the Empire Hall, where we are promised representations of the surroundings in which Newton, Faraday, Marconi and others carried on their investigations. A section of the Exhibition will be devoted to the home cinema, while close by will be the telephone exhibit of the General Post Office. Modern sanitation, heating and refrigeration apparatus, lighting schemes, general house equipment and labour-saving devices -indeed, everything for home service, comfort and recreation-are other and more usual features of the annual exhibition.

\section{Land Utilisation Maps}

The Land Utilisation Survey has produced through the Ordnance Survey two one-inch sheets embodying some results of its work. These are sheets 114, covering the area to the south-west of London, and 142, showing the Isle of Wight, Portsmouth and the southern part of the New Forest. They are published at $4 s$. each and the sheet lines are the same as those of the popular 'one-inch' maps. Results are reduced from the original 'six. inch' survey and printed in six colours over the topographical detail and contours of the original ordnance sheets-on which the rivers appear in blue. Dark green shows forest and woodland, light green meadowland and permanent pasture, brown arable or tilled land, including grass grown in rotation and land lying fallow at the time of survey, yellow heathland, moorland, common and rough hill pasture and purple garden allotments and orchards. Land that is agriculturally unproductive, including builtover land, quarries, yards and roads is shown in red. Private parks and golf courses have been divided according to the use made of the land for grazing or other purposes. The maps are beautifully produced and give a striking picture of the uses to which land in Great Britain is put and should prove invaluable for many purposes. It is hoped to publish further sheets in course of time.

\section{Dried Poultry Manure}

THE possibility of making better use of poultry manure is receiving considerable attention at the present time and in the Journal of the Ministry of Agriculture (vol. 39, p. 656) R. Sayee and F. Hanley give an interesting account of the production of kiln. dried poultry manure. The kiln, which is very similar to that used in maltings, is a ventilated brick building with a corrugated asbestos roof which is lined with asbestos sheeting. It is heated with an ordinary coke furnace and a system of flues. After a preliminary drying in the air for about two days, the manure is spread on the kiln floor to a depth of 7-8 in., being turned occasionally during treatment. The time required for the drying process depends on the state of the material, its depth on the floor, weather and other conditions, but 48 hours should be sufficient for average material 6-7 in. deep, the maximum temperature during the process usually approaching $300^{\circ} \mathrm{F}$. Four tons of manure may conveniently be treated at a time and will yield approximately two tons of dried material, which should not contain more than 7-10 per cent moisture if it is to store satisfactorily. Some loss of nitrogen during the drying is unavoidable, but analyses show that the final composition of the poultry manure closely resembles that of other organic fertilisers, which sell at $£ 310$ s. $-£ 5$ a ton, at present in considerable demand in market gardening districts. In addition, the constituents are present in a readily available form. 